\title{
Post-anthesis dry matter and nitrogen dynamics in durum wheat as affected by nitrogen supply and soil water availability
}

\author{
Laura Ercoli $^{\mathrm{a}, *}$, Leonardo Lulli ${ }^{\mathrm{b}}$, Marco Mariotti ${ }^{\mathrm{b}}$, Alessandro Masoni ${ }^{\mathrm{b}}$, Iduna Arduini ${ }^{\mathrm{b}}$ \\ a Scuola Superiore Sant'Anna, p.zza Martiri della Libertà 33, 56127 Pisa, Italy \\ ${ }^{\mathrm{b}}$ Dipartimento di Agronomia e Gestione dell'Agroecosistema, via S. Michele degli Scalzi 2, 56124 Pisa, Italy
}

Received 27 February 2007; received in revised form 6 June 2007; accepted 7 June 2007

\begin{abstract}
Durum wheat (Triticum durum Desf.) is commonly grown in dryland conditions, where environmental stress during grain filling can limit productivity and increase the dependency on stored assimilate. We investigated current assimilation and remobilization of dry matter and nitrogen during grain filling in $\mathrm{N}$ fertilized and unfertilized durum wheat subjected to different levels of water deficit during grain filling. Two durum wheat varieties, Appio and Creso, were grown in open-air containers with three rates of nitrogen fertilizer (not applied, N0; normal amount, NN; high amount, $\mathrm{NH}$ ) and four water regimes during grain filling (fully irrigated treatment, FI; low, LWS, moderate, MWS and high water stress, HWS) across 2 years. Grain yield and dry matter and $\mathrm{N}$ accumulation and remobilization were positively affected by $\mathrm{N}$ availability and negatively by water stress during grain filling. The reduction of grain yield by severe post-anthesis water stress amounted to 27 and $37 \%$ for N0 and NN, respectively, and was associated with a decrease in kernel weight. There was also a small negative effect on the number of kernels per spike. Conversely, the duration of grain filling was not modified either by water stress or by nitrogen treatments. Severe water stress also reduced dry matter accumulation and remobilization by 36 and $14 \%$ in $\mathrm{N} 0$ plants and by 48 and $25 \%$ in NH plants. Similarly, N accumulation and N remobilization was reduced by $43 \%$ and by $16 \%$ in N0 plants and by $51 \%$ and by $15 \%$ in NH plants. Conversely, low and moderate water stress did not substantially modify the patterns of dry matter and nitrogen deposition in grain. Although remobilization of dry matter and $\mathrm{N}$ was less affected by water stress than accumulation, it was not able to counterbalance the reduction of assimilation and consequently it was not able to stabilize grain yield under drought. (C) 2007 Elsevier B.V. All rights reserved.
\end{abstract}

Keywords: Accumulation; Remobilization; Water stress

\section{Introduction}

In regions with Mediterranean climate, durum wheat is typically planted in late autumn or early winter and harvested in early summer. Thus, it is generally assumed that the crop is grown when rainfall and temperature are favourable until anthesis, while during the grain filling period limited rainfall and high temperatures occur frequently and, consequently, water stress in this period is one of the major production constraints in these environments.

During grain filling, grains accumulate carbohydrates from two resources: (i) current assimilates transferred directly to the grain and (ii) assimilates redistributed from reserve pools stored

\footnotetext{
* Corresponding author. Tel.: +39 050883357; fax: +39050883215 .

E-mail address: ercoli@sssup.it (L. Ercoli).
}

in vegetative plant parts. The remobilization of assimilates originates from plant senescence, an active and ordered process that involves translocation of stored reserves from stems and sheats to grain (Gan and Amasino, 1997; Zhang et al., 1998). In bread wheat, heavy use of $\mathrm{N}$ fertilizer delay senescence, which result in much nonstructural carbohydrate left in the straw leading to reduced grain yield (Yang et al., 2001; Yang and Zhang, 2006). On the contrary, water stress during grain filling may induce early senescence, shortening the grain filling period but increasing remobilization of assimilates from the straw to the grain (Gallagher et al., 1976; Biddinger et al., 1977; Austin et al., 1980; Kobata et al., 1992). Palta et al. (1994) found that postanthesis assimilation was reduced by $57 \%$ in drought conditions, while remobilization of reserves was increased by $36 \%$. Even the rate of development of water deficit may affect mobilization: total grain carbon was reduced by $24 \%$ with a rapid water deficit rate relative to a slow rate (Palta et al., 1994). Gallagher et al. (1976) estimated that pre-anthesis reserves contributed up 
to $74 \%$ to grain yield of wheat when crops suffered from severe post-anthesis drought.

Nitrogenous fertilizers influence yield and grain protein percentage to varying degrees, depending on the rate and timing of the $\mathrm{N}$ application, on the level and form of soil $\mathrm{N}$ and on available water in soil (Spiertz and De Vos, 1983; Borghi et al., 1997), but the degree of influence is governed by annual weather conditions and by residual soil N (López-Bellido et al., 2001). High availability of soil $\mathrm{N}$ during grain filling favours post-anthesis $\mathrm{N}$ uptake and reduces the remobilization of preanthesis N (Papakosta and Gagianas, 1991). Campbell et al. (1993) reported a strong interaction between soil water availability and crop fertilizer response in semi-arid conditions, with inefficient use of available $\mathrm{N}$ in years of severe water stress. van Herwaarden et al. (1998a,b) demonstrated that in bread wheat water deficit during grain filling reduced assimilation and consequently grain yield, and high- $\mathrm{N}$ crops suffered greater reduction compared to unfertilized ones. The lower grain yield of crops with high-nitrogen status at low water availability appears to be due to either incomplete remobilization of reserves or reduction in the amount of reserves available for remobilization.

Contrasting results are reported in literature about the relative contribution to grain yield of current assimilation and remobilization during grain filling. In bread wheat, many authors have found that an enhancement of remobilization of pre-stored carbon and $\mathrm{N}$ reserves to grain partially compensates the reduced current assimilation due to water stress (Kobata et al., 1992; Palta et al., 1994; Yang et al., 2000; Xu et al., 2006). Others have shown that both post-anthesis photosynthesis and remobilized assimilates are negatively affected (Ozturk and Aydin, 2004; Plaut et al., 2004; Edhaie et al., 2006; Pampana et al., 2007). In order to interpretate these results and extrapolate them to other sites, simulation models were successfully applied, providing a powerful mean of integrating all factors affecting wheat growth (Asseng et al., 1998, 2001; Pan et al., 2007). Following Asseng and van Herwaarden (2003), in each environment the relative contribution of remobilization to grain yield depends mainly on source/sink interactions during grain filling. If the crop grows essentially non-water-limited up to anthesis, the greater accumulation of pre-grain filling reserves are expected to confer a yield advantage, especially at higher N status. However, increasing the storage capacity by high pre-anthesis growth will not be effective in increasing grain yields if growth shortly before and after anthesis is limited by periods of drought or by $\mathrm{N}$ supply.

While yield performance of bread wheat in relation to current assimilation and remobilization during grain filling have been extensively studied, only limited information is available on durum wheat. However, both species respond differently to environmental conditions, especially in areas where drought stress usually constrain yield potential during grain filling (Ehdaie and Waines, 2001; Moragues et al., 2006). Therefore, the objective of this research was to investigate in durum wheat current assimilation and remobilization of dry matter and nitrogen during grain filling in $\mathrm{N}$ fertilized and unfertilized plants subjected to different levels of water deficit during grain filling.

\section{Material and methods}

\subsection{Location and experimental design}

The research was carried out in 1999-2000 and 2000-2001 at the Department of Agronomy and Agroecosystem Management of the University of Pisa, Italy $\left(43^{\circ} 40^{\prime} \mathrm{N}, 10^{\circ} 19^{\prime} \mathrm{E}\right.$ and $1 \mathrm{~m}$ above sea level). The climate is hot, humid Mediterranean with mean annual maximum and minimum daily air temperatures of 20.2 and $9.5^{\circ} \mathrm{C}$, respectively, and precipitation of $971 \mathrm{~mm}$, with $663 \mathrm{~mm}$ received from November through June, corresponding to wheat growing season (Moonen et al., 2001).

In each year, durum wheat crops were grown in semicontrolled conditions with different $\mathrm{N}$ supply and watering regimes. Two durum wheat (Triticum durum Desf.) varieties, Appio and Creso, currently used in local production, were grown with three rates of nitrogen fertilizer (not applied, N0; normal amount, NN, $120 \mathrm{~kg} \mathrm{Nha}^{-1}$ and high amount, $\mathrm{NH}$, $180 \mathrm{~kg} \mathrm{~N} \mathrm{ha}^{-1}$ ) and four water regimes during grain filling (fully irrigated treatment, FI; low water stress treatment, LWS; moderate water stress treatment, MWS and high water stress treatment, HWS). To determine remobilization during grain filling, plants were harvested at anthesis (stage 60 of the scale of Zadoks et al., 1974) and physiological maturity (stage 90). For each year and harvest stage, the experiment was arranged in a randomized block design with three replications and was carried out using 72 containers of $100-\mathrm{L}$ volume $\left(0.25-\mathrm{m}^{2}\right.$ area and $0.4-\mathrm{m}$ height). Containers were placed outdoors and arranged in two rows of 36 , spaced $10 \mathrm{~cm}$ and were embedded in expanded clay to smooth daily fluctuations in soil temperature. Containers were filled with a loam soil tamped to about original soil bulk density, and were attached to a 5-cm rigid PVC drain that ended in a central collection facility.

Soil chemical and physical properties were $50.9 \%$ sand, $34.5 \%$ silt, $14.6 \%$ clay (USDA method), $8.1 \mathrm{pH}, 2.5 \%$ organic matter (Walkley and Black method), $1.2 \mathrm{~g} \mathrm{~kg}^{-1}$ total nitrogen (Kjeldahl method), $22.0 \mathrm{mg} \mathrm{kg}^{-1}$ available $\mathrm{P}$ (Olsen method), $72.4 \mathrm{mg} \mathrm{kg}^{-1}$ available K (Dirks-Sheffer method), $22.9 \%$ field capacity, $10.9 \%$ permanent wilting point. Field capacity and permanent wilting point were determined at 33 and $1500 \mathrm{kPa}$ soil water tension using the pressure chamber method.

Varieties were sown on 18 November 1999 and on 28 November 2000 at a rate of 400 viable seeds per $\mathrm{m}^{2}$ in rows spaced $15 \mathrm{~cm}$ apart. The rate of $120 \mathrm{~kg} \mathrm{ha}^{-1}$ of $\mathrm{N}$ fertilization was splitted $50 \%$ preplanting as ammonium nitrate, and $50 \%$ at first node detectable (stage 31) as urea. The rate of $180 \mathrm{~kg} \mathrm{ha}^{-1}$ of $\mathrm{N}$ fertilization was splitted $33 \%$ preplantig as ammonium nitrate, $33 \%$ at first node detectable and 34\% 15 days after this stage, as urea. Phosphorus and potassium were applied preplanting as triple mineral phosphate and potassium sulphate at a rate of $100 \mathrm{~kg} \mathrm{ha}^{-1} \mathrm{P}_{2} \mathrm{O}_{5}$ and $\mathrm{K}_{2} \mathrm{O}$. Fertilizer rates were those conventionally applied in Tuscany.

At anthesis, all containers were irrigated to $100 \%$ field capacity, based on estimated water holding capacity of the soil, using a drip/trickle microirrigation system consisting in two compensating emitters per container at a rate of discharge of $2 \mathrm{~L} \mathrm{~h}^{-1}$ per emitter. Four different water regimes were imposed and 
maintained until maturity. They consisted of daily irrigation replacing about 100, 50, 75 and $25 \%$ estimated crop evapotranspiration (ET), representing, respectively, fully irrigated treatment $(\mathrm{FI})$, low water stress treatment (LWS), moderate water stress treatment (MWS) and high water stress treatment (HWS). Crop ET was estimated as PET $\times k_{\mathrm{c}}$, using the $k_{\mathrm{c}}$ values calculated by Tarantino and Onofrii (1991) for wheat cropped in a similar environment. As a whole, 107, 90, 74 and $57 \mathrm{~mm}$ irrigation were supplied, respectively, for FI, LWS, MWS and HWS $\mathrm{mm}$ in 2000 and 91, 78, 63 and $49 \mathrm{~mm}$ in 2001.

\subsection{Sampling and analytical procedures}

At anthesis (3 May 2000 and 2 May 2001) and maturity (20 June 2000 and 19 June 2001) the plants in each container were harvested. Plants were cut at ground level and separated into leaves, culms and spikes at anthesis, and into leaves, culms, chaff and grain at maturity. Roots were separated from the soil by washing with water until they were totally clean. Part of the roots was frozen for the determination of root length. All the other plant parts were oven dried at $65^{\circ} \mathrm{C}$ to constant weight for dry weight determination. Number of spikes per unit area was determined both at anthesis and maturity, LAI was measured at anthesis, while mean kernel weight, number of kernels per spike, and harvest index (HI) were measured at maturity. Plant samples were analyzed for nitrogen concentration (microKjeldahl) and $\mathrm{N}$ contents were calculated by multiplying the $\mathrm{N}$ concentration by dry weight. Nitrogen harvest index (NHI) was calculated as $(\mathrm{N}$ content of grain/ $\mathrm{N}$ content of aerial plant part $) \times 100$. The length of roots was determined after the sample was defrosted at $5{ }^{\circ} \mathrm{C}$. Ten sub-samples were weighed (about $50 \mathrm{mg}$ each) and placed in Petri plates upon a film of water. Length of roots of subsamples was determined using a computerized image analyzer Leica Quantimet 500 and related to the whole root system length.

The number of vitreous kernels was determined by visual inspection of 200 grains sliced with a Pohl grain cutter. Grains were milled to flour using a Labormill 4RB. Dry gluten concentration was determined using the Glutomatic system following the standard method ICC no. 137. SDS-sedimentation test (height of sediment in $\mathrm{mm}$ ) was performed according to Dick and Quick (1983).

The following parameters, related to dry matter and $\mathrm{N}$ accumulation and remobilization within the wheat plant, were calculated following Arduini et al. (2006) and Masoni et al. (2007), as:

- post-anthesis dry matter and $\mathrm{N}$ accumulation as the difference between dry matter or $\mathrm{N}$ content of the whole plant at anthesis and at physiological maturity;

- dry matter remobilization $(\mathrm{DMR})=\mathrm{DM}$ at anthesis - dry matter of roots, leaves, culms and chaff at maturity;

- nitrogen remobilization $(\mathrm{NR})=$ content of $\mathrm{N}$ of the whole plant at anthesis - content of $\mathrm{N}$ of roots, leaves, culms and chaff at maturity;

- dry matter remobilization efficiency $=(D M R /$ dry matter of the whole plant at anthesis) $\times 100$;
- nitrogen remobilization efficiency $=(\mathrm{NR} /$ content of $\mathrm{N}$ of the whole plant at anthesis) $\times 100$;

- contribution of dry matter remobilization to grain = $(\mathrm{DMR} /$ grain yield at maturity) $\times 100$;

- contribution of $\mathrm{N}$ remobilization to grain $\mathrm{N}$ content $=$ $(\mathrm{NR} /$ grain $\mathrm{N}$ content at maturity) $\times 100$.

For the estimate of DMR and NR it was assumed that all of the dry matter and $\mathrm{N}$ lost from vegetative plant parts was remobilized to the developing grain, since losses of dry matter due to plant respiration and losses of $\mathrm{N}$ due to volatilization during grain filling were not determined.

\subsection{Climatic conditions}

Daily weather data were obtained from a meteorological station within $100 \mathrm{~m}$ of the plot location.

Rainfall between planting and anthesis did not vary appreciably between years of cultivation, totalling $390 \mathrm{~mm}$ in November 2000-April 2001 and $414 \mathrm{~mm}$ in November 2001-April 2002. Rainfall during grain filling was also similar in 2001 (29 mm) and in $2002(35 \mathrm{~mm})$. For both years rainfall in the period planting-anthesis was lower than the long-term average, while rainfall during grain filling was similar.

Air temperatures prior anthesis and from anthesis to maturity were close to the long-term average and similar in both years. Consequently, the thermal time up to anthesis and during grain filling did not vary substantially between years and were 1491 GDD and 985 GDD in 2000 and 1725 GDD and 984 GDD in 2001 .

\subsection{Statistical analysis}

Data were statistically treated by ANOVA, performed separately for each harvest. At anthesis the effects of year (Y), variety $(\mathrm{V}), \mathrm{N}$ rate $(\mathrm{N})$ and their interactions were tested and at maturity the effects of year $(\mathrm{Y})$, variety $(\mathrm{V}), \mathrm{N}$ rate $(\mathrm{N})$, soil water availability (W) and their interactions were tested. Because the main effect of year and its interactions were not significant at both stages, a successive analysis of variance was carried out using years as replications. Duncan's multiple range test was used to separate the means when the ANOVA $F$-test indicated a significant effect of the treatment (Steel et al., 1997).

\section{Results}

\subsection{Plant growth and $N$ uptake at anthesis}

At anthesis, only nitrogen and variety effects were tested, since the irrigation treatments were imposed during grain filling. Analysis of variance did not show any significant difference between the two varieties for any character; therefore only $\mathrm{N}$ rate effects were discussed in the paper for this stage. Indeed, the varieties Appio and Creso compared in this research were similar for genetic background, yield potential and phenology, while, to our knowledge, no information was available about their drought tolerance. 
Table 1

Dry weight and $\mathrm{N}$ concentration and content of leaves, culms, spikes, roots and whole plant at anthesis as affected by $\mathrm{N}$ rate

\begin{tabular}{lcccrr}
\hline N rate & Leaves & Culms & Spikes & Roots & Whole plant \\
\hline \multicolumn{2}{l}{ Dry weight $\left(\mathrm{g} \mathrm{m}^{-2}\right)$} & & & & \\
$\mathrm{N} 0$ & $139.7 \mathrm{a}$ & $465.5 \mathrm{a}$ & $99.4 \mathrm{a}$ & $56.0 \mathrm{a}$ & $760.6 \mathrm{a}$ \\
$\mathrm{NL}$ & $197.8 \mathrm{~b}$ & $602.4 \mathrm{~b}$ & $144.7 \mathrm{~b}$ & $81.6 \mathrm{~b}$ & $1026.5 \mathrm{~b}$ \\
$\mathrm{NH}$ & $219.4 \mathrm{c}$ & $656.1 \mathrm{c}$ & $179.3 \mathrm{c}$ & $84.7 \mathrm{c}$ & $1139.5 \mathrm{c}$ \\
$\mathrm{N} \mathrm{concentration}\left(\mathrm{g} \mathrm{kg}^{-1}\right)$ & & & & \\
$\mathrm{N} 0$ & $15.5 \mathrm{a}$ & $4.7 \mathrm{a}$ & $14.9 \mathrm{a}$ & $7.6 \mathrm{a}$ & $9.1 \mathrm{a}$ \\
$\mathrm{NL}$ & $18.8 \mathrm{~b}$ & $4.9 \mathrm{ab}$ & $15.5 \mathrm{ab}$ & $9.9 \mathrm{~b}$ & $9.8 \mathrm{a}$ \\
$\mathrm{NH}$ & $21.4 \mathrm{c}$ & $5.1 \mathrm{~b}$ & $16.6 \mathrm{~b}$ & $10.2 \mathrm{~b}$ & $12.2 \mathrm{~b}$ \\
$\mathrm{~N} \mathrm{content}\left(\mathrm{kg} \mathrm{ha}^{-1}\right)$ & & & & \\
$\mathrm{N} 0$ & $21.7 \mathrm{a}$ & $21.9 \mathrm{a}$ & $14.8 \mathrm{a}$ & $4.3 \mathrm{a}$ & $62.6 \mathrm{a}$ \\
$\mathrm{NL}$ & $37.2 \mathrm{~b}$ & $29.5 \mathrm{~b}$ & $22.4 \mathrm{~b}$ & $8.1 \mathrm{~b}$ & $97.2 \mathrm{~b}$ \\
$\mathrm{NH}$ & $47.0 \mathrm{c}$ & $33.5 \mathrm{c}$ & $29.8 \mathrm{c}$ & $8.6 \mathrm{~b}$ & $118.8 \mathrm{c}$ \\
\hline
\end{tabular}

Values followed by the same letter are not significantly different at $P \leq 0.05$.

The dry weight and the $\mathrm{N}$ concentration and content of all plant parts increased with the increase of $\mathrm{N}$ rate (Table 1). Compared to unfertilized control, the highest $\mathrm{N}$ rate increased dry matter of the whole plant by $50 \%$, owing to higher leaf $(57 \%)$, culm $(41 \%)$, spike $(80 \%)$ and root $(51 \%)$ dry weight. Nitrogen fertilization also increased leaf area index and root length from 3 to $4.6 \mathrm{~m}^{2} \mathrm{~m}^{-2}$ and from 24.3 to $34 \mathrm{~km} \mathrm{~m}^{-2}$, respectively, in $\mathrm{N} 0$ and NH plants (results not shown). Owing to the increase of both dry weight and $\mathrm{N}$ concentration in all plant parts, $\mathrm{N}$ content of the whole plant was by $48 \%$ higher in the $\mathrm{NH}$ compared to N0 treatment, owing to higher leaf $(63 \%)$, culm $(29 \%)$, spike $(51 \%)$ and root $(64 \%) \mathrm{N}$ content (Table 1$)$.
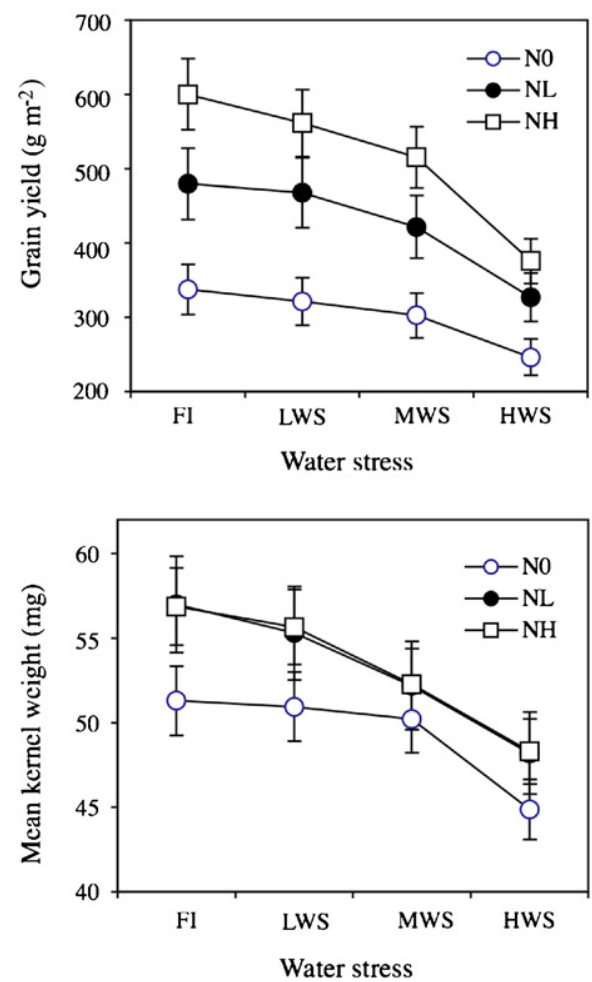

\subsection{Post-anthesis responses to water stress}

No significant effect of variety was detected at maturity as well, therefore only the $\mathrm{N}$ rate and water availability effects are discussed.

\subsubsection{Grain yield and yield components}

Grain yield, averaged over varieties, increased with the gain of $\mathrm{N}$ rate and decreased with the increase of water stress during grain filling, but the decrease was higher with the greatest $\mathrm{N}$ rate (by $37 \%$ at $\mathrm{NH}$ and only by $27 \%$ at N0). As a consequence, the increase in grain yield due to $\mathrm{NH}$ was $78 \%$ at FI and $53 \%$ at HWS (Fig. 1).

As the irrigation treatments were imposed after anthesis, the constraints of water stress occurred after the structure of the crop was almost set, so uniform spike density within irrigation treatments was expected. Indeed, the number of spikes per unit area was not affected by irrigation and slightly increased due to nitrogen fertilizer (from 461 spikes per $\mathrm{m}^{2}$ of $\mathrm{N} 0$ to 500 of $\mathrm{NH}$ ).

The number of kernels per spike and the mean kernel weight were significantly affected by the interaction of irrigation and the $\mathrm{N}$ rate, increasing with the $\mathrm{N}$ rate and decreasing with water deficit (Fig. 1). Moderate and severe water stress significantly reduced the number of kernels per spike in N0 plants, while in NL and $\mathrm{NH}$ plants only severe water stress reduced this parameter. The increase of water stress progressively reduced mean kernel weight of both NL and NH plants, while in N0 plants only HWS reduced this parameter significantly. Thus, the growth of kernels in plants limited by $\mathrm{N}$ was further limited only by severe water stress, while in $\mathrm{N}$-fertilized plants water stress limited the growth
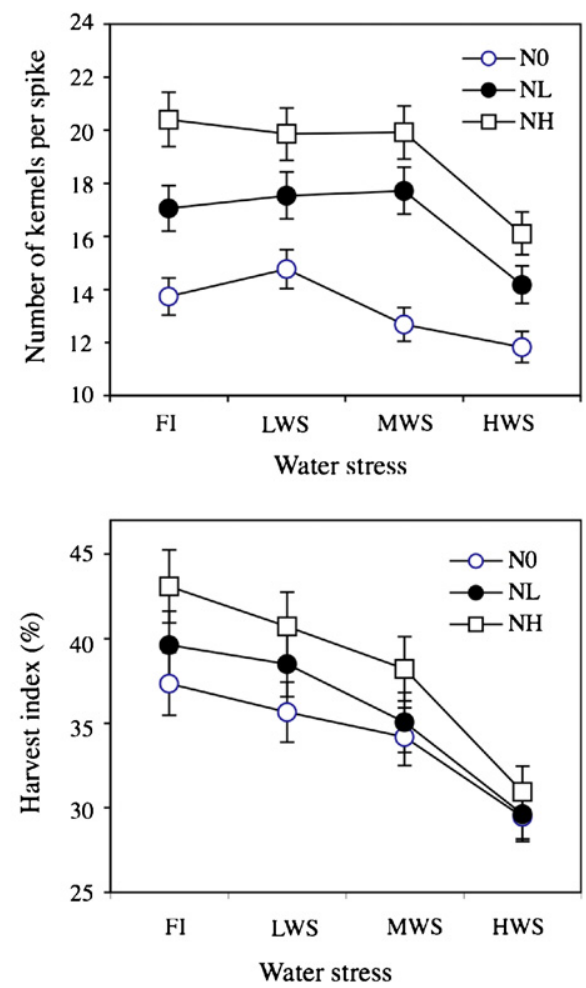

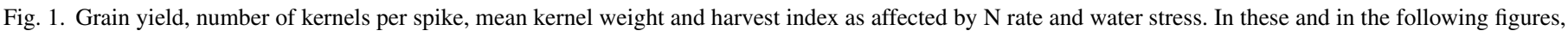
vertical bars indicate standard error. 
Table 2

Dry weight of leaves, culms, chaff and whole plant at physiological maturity as affected by $\mathrm{N}$ rate and water stress

\begin{tabular}{|c|c|c|c|c|}
\hline \multirow[t]{2}{*}{ Treatment } & \multicolumn{4}{|c|}{ Dry weight $\left(\mathrm{g} \mathrm{m}^{-2}\right)$} \\
\hline & Leaves & Culms & Chaff & Whole plant \\
\hline \multicolumn{5}{|l|}{$\mathrm{N}$ rate } \\
\hline N0 & $109.7 \mathrm{a}$ & $401.4 \mathrm{a}$ & $68.9 \mathrm{a}$ & $935.6 \mathrm{a}$ \\
\hline NL & $149.7 b$ & $494.8 b$ & $114.7 \mathrm{~b}$ & $1252.5 b$ \\
\hline $\mathrm{NH}$ & $148.1 b$ & $540.0 \mathrm{c}$ & $132.6 \mathrm{c}$ & $1415.0 \mathrm{c}$ \\
\hline \multicolumn{5}{|c|}{ Water stress } \\
\hline FI & $131.9 \mathrm{a}$ & $458.3 \mathrm{a}$ & $106.2 \mathrm{a}$ & $1235.4 \mathrm{a}$ \\
\hline LWS & $133.4 \mathrm{a}$ & 477.0ab & $104.6 \mathrm{a}$ & $1226.8 \mathrm{a}$ \\
\hline MWS & $137.7 \mathrm{a}$ & $490.2 b$ & $104.6 \mathrm{a}$ & $1211.3 \mathrm{a}$ \\
\hline HWS & $140.1 \mathrm{a}$ & $489.3 b$ & $106.2 \mathrm{a}$ & $1130.7 b$ \\
\hline
\end{tabular}

Within treatment $\mathrm{N}$ rate and water stress, values followed by the same letter are not significantly different at $P \leq 0.05$.

of kernels even at a mild level. To summarize, the structure of the spike was significantly modified by $\mathrm{N}$ and water stress and the variations of grain yield were due to a reduction of both head and kernel size. In addition, the positive effect of $\mathrm{N}$ on both characters decreased with the increase of water stress.

The harvest index was also affected by the interaction of the $\mathrm{N}$ rate and water deficit and decreased with the increase of water stress, but the decrease was higher with the highest $\mathrm{N}$ rate. As a consequence, at severe water stress $\mathrm{HI}$ was about $30 \%$, no matter was the $\mathrm{N}$ rate, whereas at full irrigation it increased from $37 \%$ in N0 plants to $43 \%$ in NH plants (Fig. 1).

\subsubsection{Dry matter and $N$ uptake}

At maturity, the dry weight of leaves, culms and chaff was not affected by the interaction between the $\mathrm{N}$ rate and water deficit, while the root dry weight was affected. Averaged over irrigation treatments, the $\mathrm{N}$ rate significantly increased the dry weight of leaves, culms and chaff (Table 2). Water deficit during grain filling did not modify leaf and chaff dry weight and increased culm dry weight at MWS and HWS. The nitrogen rate increased root dry weight and the increase was higher with the most severe water stress: indeed, roots of unfertilized plants were not modified by water deficit, whereas those of fertilized ones moderately increased at MWS and highly increased at HWS (Fig. 2). Over-

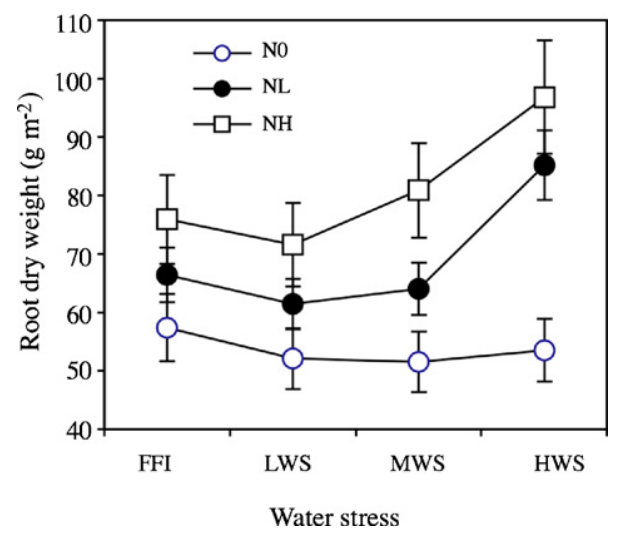

Fig. 2. Dry weight of roots at physiological maturity as affected by $\mathrm{N}$ rate and water stress.

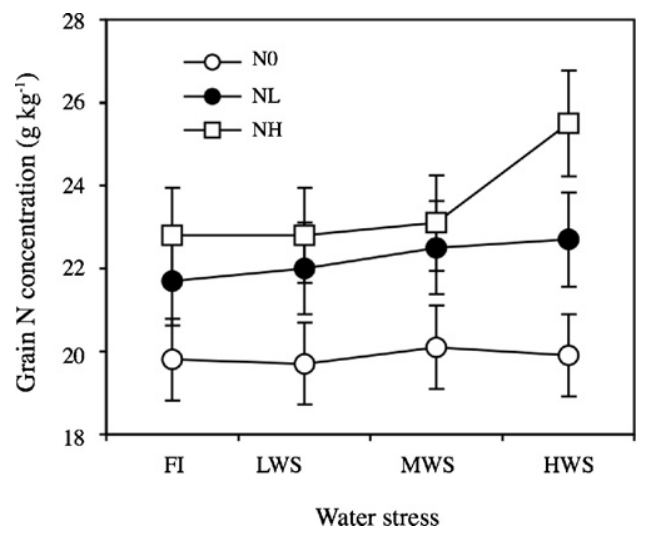

Fig. 3. Nitrogen concentration in grain at physiological maturity as affected by $\mathrm{N}$ rate and water stress.

all, the vegetative plant part (leaves, culms, chaff and roots) of $\mathrm{NH}$ plants was $42 \%$ higher than N0 plants and that of FI plants was $7 \%$ higher than HWS plants.

At maturity, the interaction $\mathrm{N}$ rate $\times$ water stress was significant only for grain $\mathrm{N}$ concentration. With the increase of $\mathrm{N}$ rate, grain $\mathrm{N}$ concentration increased and was not significantly modified by water stress with the exception of HWS in NH plants, where it was $12 \%$ higher than with MWS (Fig. 3). The nitrogen rate increased $\mathrm{N}$ concentration of culms and roots, while it did not modify $\mathrm{N}$ concentration of leaves and chaff (Table 3). Conversely, water stress significantly increased $\mathrm{N}$ concentration of leaves and culms and did not modify it in the roots and chaff.

The nitrogen content of all plant parts was affected by the interaction between the $\mathrm{N}$ rate and water stress, but the pattern of response differed among organs. Grain N content increased with the increase of $\mathrm{N}$ rate and decreased with water stress, and the decrease between FI and HWS was about $29 \%$ with all three $\mathrm{N}$ treatments (Fig. 4). Leaf and culm $\mathrm{N}$ content increased with the increase of water stress and the $\mathrm{N}$ rate: from FI to HWS there was a $17 \%$ increase in the leaves at N0 and a $45 \%$ one at NL and $\mathrm{NH}$, whereas in culms there was a $40 \%$ increase at $\mathrm{N} 0$ and a $20 \%$ one at NL and NH (Fig. 4). The root $\mathrm{N}$ content of unfertilized plants did not vary with the increase of water stress, while that of $\mathrm{NL}$ and $\mathrm{NH}$ plants increased with the two most severe water

Table 3

Nitrogen concentration of leaves, culms, roots and chaff at physiological maturity as affected by $\mathrm{N}$ rate and water stress

\begin{tabular}{lllll}
\hline Treatment & \multicolumn{4}{l}{ Nitrogen concentration $\left(\mathrm{g} \mathrm{kg}^{-1}\right)$} \\
\cline { 2 - 5 } & Leaves & Culms & Roots & Chaff \\
\hline N rate & & & \\
N0 & $8.4 \mathrm{a}$ & $3.1 \mathrm{a}$ & $8.4 \mathrm{a}$ & $4.9 \mathrm{a}$ \\
NL & $8.2 \mathrm{a}$ & $3.8 \mathrm{~b}$ & $8.7 \mathrm{ab}$ & $5.3 \mathrm{a}$ \\
NH & $9.0 \mathrm{a}$ & $3.9 \mathrm{~b}$ & $9.2 \mathrm{~b}$ & $5.0 \mathrm{a}$ \\
Water stress & & & & \\
FI & $7.6 \mathrm{a}$ & $3.4 \mathrm{a}$ & $8.6 \mathrm{a}$ & $4.9 \mathrm{a}$ \\
LWS & $8.0 \mathrm{a}$ & $3.6 \mathrm{ab}$ & $8.8 \mathrm{a}$ & $5.0 \mathrm{a}$ \\
MWS & $8.8 \mathrm{~b}$ & $3.7 \mathrm{ab}$ & $9.0 \mathrm{a}$ & $5.1 \mathrm{a}$ \\
HWS & $9.7 \mathrm{c}$ & $3.9 \mathrm{~b}$ & $8.9 \mathrm{a}$ & $5.2 \mathrm{a}$ \\
\hline
\end{tabular}

Within treatment $\mathrm{N}$ rate and water stress, values followed by the same letter are not significantly different at $P \leq 0.05$. 

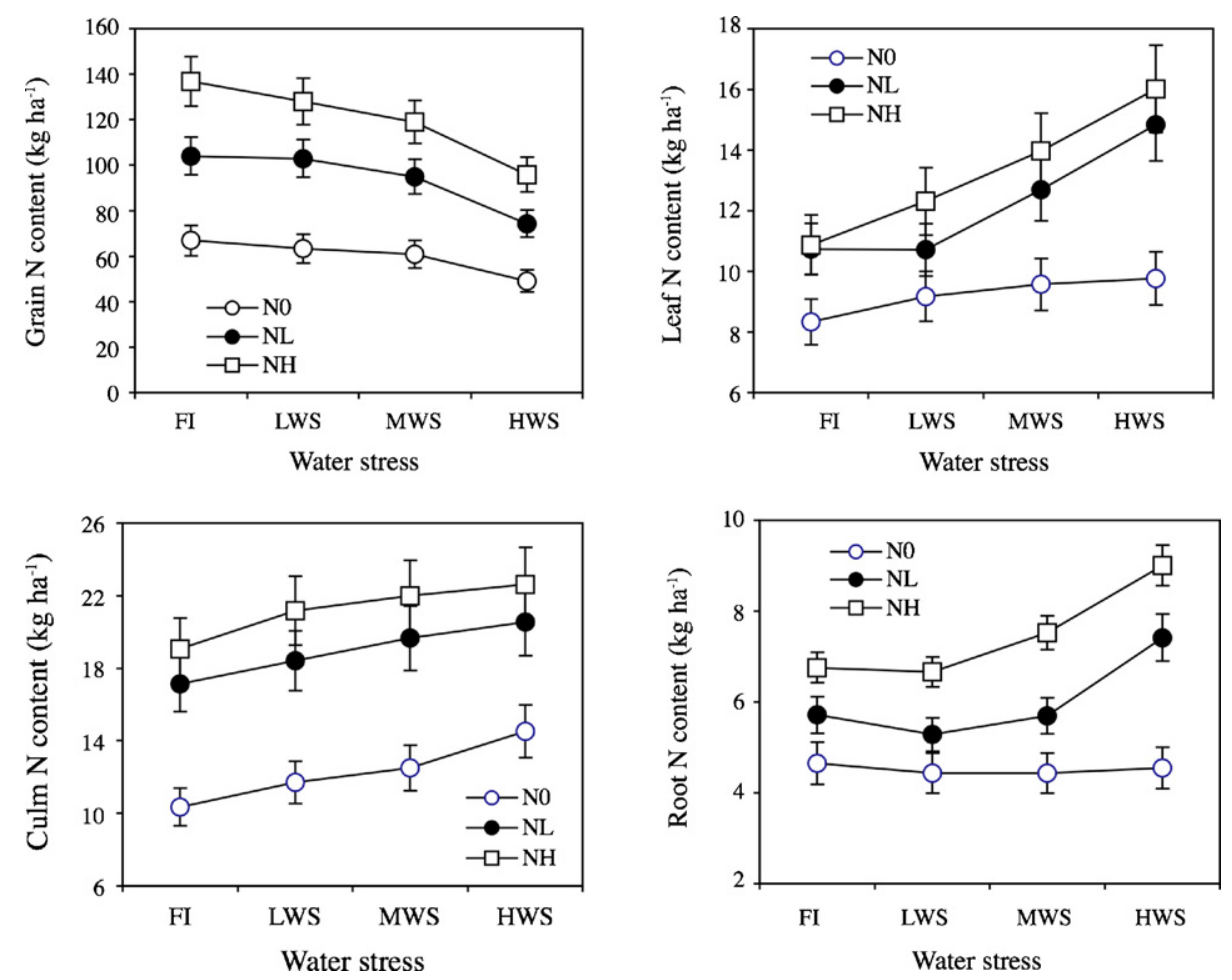

Fig. 4. Nitrogen content of grain, leaves, culms and roots at physiological maturity as affected by $\mathrm{N}$ rate and water stress.

stresses. At HWS the root $\mathrm{N}$ content was $63 \%$ higher in NL plants and $100 \%$ higher in NH plants, compared to N0 plants (Fig. 4).

The nitrogen harvest index was not affected by the interaction of $\mathrm{N}$ rate and water stress. Averaged over water stress treatments, $\mathrm{NHI}$ increased from about $69 \%$ at $\mathrm{N} 0$ to $73 \%$ at NH and, averaged over $\mathrm{N}$ rates, it decreased from 75 at FI to $64 \%$ at HWS (results not shown).

Most of the N uptake of wheat plants occurred before anthesis and the proportion was unaffected by the $\mathrm{N}$ rate. On average, by anthesis, plants accumulated about $75 \%$ of total $\mathrm{N}$ content recorded at maturity.

\subsubsection{Accumulation and remobilization of dry matter}

Dry matter accumulation during grain filling was affected positively by the $\mathrm{N}$ rate and negatively by water stress. The decrease due to water stress was higher in NH plants $\left(1.6 \mathrm{tha}^{-1}\right)$ than in $\mathrm{N} 0$ and $\mathrm{NL}$ plants $\left(0.7 \mathrm{tha}^{-1}\right)$ (Fig. 5). As a consequence, at FI the increase in post-anthesis dry matter accumulation due to $\mathrm{N}$ fertilization was $1.9 \mathrm{tha}^{-1}$ while at HWS it was only $0.4 \mathrm{tha}^{-1}$.

The amount of remobilized dry matter during grain filling was increased by the $\mathrm{N}$ rate at all water stress treatments, and was decreased by water stress only in $\mathrm{N}$ fertilized plants (Fig. 5). The decrease of remobilization due to severe water stress was about $0.7 \mathrm{tha}^{-1}$ in both NL and NH plants. Thus, the difference of remobilized dry matter between $\mathrm{NH}$ and $\mathrm{N} 0$ plants was $1.4 \mathrm{tha}^{-1}$ at FI and $0.9 \mathrm{tha}^{-1}$ at HWS.

Overall, the contribution of culms to the remobilization of dry matter to grain was almost double that of leaves; the proportion was not modified by either the $\mathrm{N}$ rate or water stress. Leaves and culms accounted for about $80 \%$ of remobilized dry matter in grain, the remaining $20 \%$ was given by roots and chaff.

Post-anthesis remobilization efficiency of dry matter increased with the $\mathrm{N}$ rate and decreased with water stress: in unfertilized plants the efficiency decreased from 18 to $15 \%$, while in NL and NH plants it decreased from 24 to $16 \%$ (Fig. 5).

The contribution of dry matter remobilization to grain yield was increased by the N rate from $42 \%$ of N0 plants to $47 \%$ of $\mathrm{NL}$ and $\mathrm{NH}$ plants, and by water stress from $45 \%$ at FI, LWS and MWS to $51 \%$ at HWS (Table 4).

\subsubsection{Accumulation and remobilization of nitrogen}

Nitrogen accumulation in durum wheat during grain filling was affected positively by $\mathrm{N}$ rate and negatively by water stress.

Table 4

Contribution of dry matter remobilized to grain yield (CDMR), post-anthesis nitrogen remobilized into grain (NR), nitrogen remobilization efficiency (NRE) and contribution of $\mathrm{N}$ remobilized to $\mathrm{N}$ content of grain (CNR) as affected by $\mathrm{N}$ rate and water stress

\begin{tabular}{lllll}
\hline Treatment & CDMR $(\%)$ & NR $\left(\mathrm{kg} \mathrm{ha}^{-1}\right)$ & NRE $(\%)$ & CNR $(\%)$ \\
\hline N rate & & & & \\
N0 & $42.1 \mathrm{a}$ & $33.2 \mathrm{a}$ & $53.1 \mathrm{a}$ & $55.4 \mathrm{a}$ \\
NL & $46.7 \mathrm{~b}$ & $54.0 \mathrm{~b}$ & $55.5 \mathrm{ab}$ & $57.4 \mathrm{ab}$ \\
NH & $46.3 \mathrm{~b}$ & $70.2 \mathrm{c}$ & $59.1 \mathrm{~b}$ & $58.6 \mathrm{~b}$ \\
Water stress & & & & \\
FI & $45.0 \mathrm{a}$ & $56.4 \mathrm{a}$ & $60.8 \mathrm{a}$ & $55.0 \mathrm{a}$ \\
LWS & $44.2 \mathrm{a}$ & $54.4 \mathrm{ab}$ & $58.6 \mathrm{ab}$ & $55.0 \mathrm{a}$ \\
MWS & $43.0 \mathrm{a}$ & $51.5 \mathrm{~b}$ & $55.4 \mathrm{~b}$ & $56.2 \mathrm{a}$ \\
HWS & $51.0 \mathrm{~b}$ & $47.6 \mathrm{c}$ & $51.2 \mathrm{c}$ & $65.1 \mathrm{~b}$ \\
\hline
\end{tabular}

Within treatment $\mathrm{N}$ rate and water stress, values followed by the same letter are not significantly different at $P \leq 0.05$. 

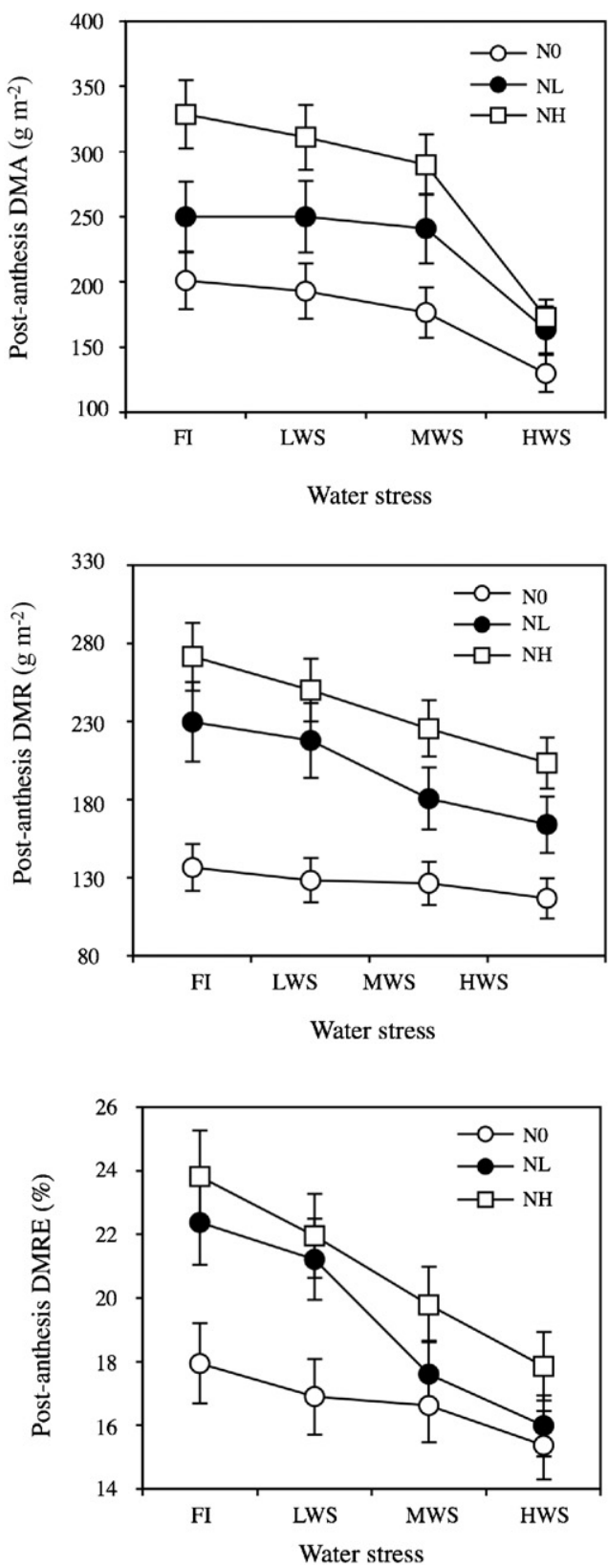

Fig. 5. Post-anthesis dry matter accumulation (DMA), remobilization into grain (DMR) and remobilization efficiency (DMRE) as affected by $\mathrm{N}$ rate and water stress.

However, the effect of water stress was inconsistent up to HWS in N0 and NL plants, while it was significant at all water stress treatments in $\mathrm{NH}$ plants. As a consequence, the increase in $\mathrm{N}$ accumulation due to $\mathrm{N}$ rate was $30 \mathrm{~kg} \mathrm{ha}^{-1}$ at FI and $13 \mathrm{~kg} \mathrm{ha}^{-1}$ at HWS (Fig. 6).

The $\mathrm{N}$ rate increased the amount of remobilized $\mathrm{N}$ and the efficiency of $\mathrm{N}$ remobilization and the contribution of remobilized $\mathrm{N}$ to $\mathrm{N}$ grain content; the increase was quite great for the former and slight for the latter (Table 4). Between NO and NH, remobilized $\mathrm{N}$ increased by $37 \mathrm{~kg} \mathrm{ha}^{-1}$, efficiency of remobilization by $6 \%$ and the contribution of $\mathrm{N}$ remobilized to grain $\mathrm{N}$ content by $3 \%$. The increase of water stress from FI to HWS decreased remobilized $\mathrm{N}$ by $9 \mathrm{~kg} \mathrm{ha}^{-1}$ and efficiency of $\mathrm{N}$ remobilization

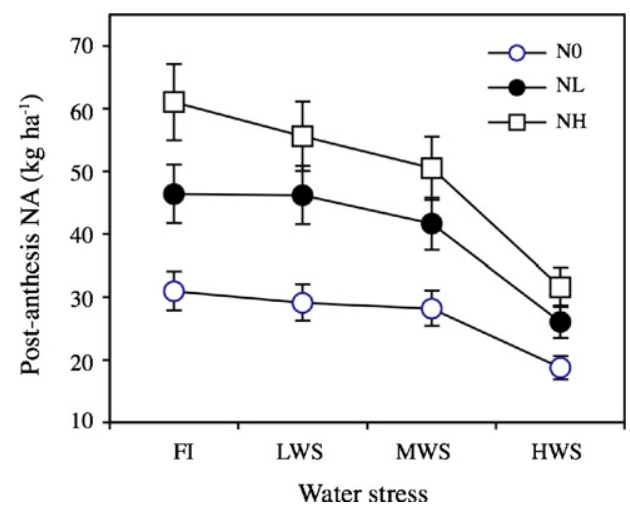

Fig. 6. Post-anthesis nitrogen accumulation (NA) as affected by $\mathrm{N}$ rate and water stress.

by $10 \%$, while it increased the contribution of $\mathrm{N}$ remobilization to grain $\mathrm{N}$ content by $10 \%$.

Differently from dry matter, the contribution of leaves in remobilization of $\mathrm{N}$ to grain was almost double than that of culms and the proportion was not modified either by the $\mathrm{N}$ rate or by water stress. Leaves and culms accounted for about $65 \%$ of remobilized nitrogen in grain, the remaining $35 \%$ was given almost completely by chaff.

In all treatments, the mass of remobilized $\mathrm{N}$ was $1.2-2.0$ times the mass of $\mathrm{N}$ taken up from the soil. At each $\mathrm{N}$ rate, the proportion increased with the increase of water stress severity.

\subsubsection{Grain quality}

The average protein concentration in grain, calculated by applying to $\mathrm{N}$ concentration a protein to $\mathrm{N}$ ratio of 5.7, ranged from $12.5 \%$ in NL plants to $14.6 \%$ in NH plants, figures that are both appropriate for semolina production according to the Italian industry standard. At N0, on the contrary, the quality obtained is to be considered low, averaging $11.4 \%$.

The nitrogen rate and water deficit modified all quality characteristics of grain (Table 5). The percentage of vitreous kernels increased from 65 to $86 \%$ with the increase of $\mathrm{N}$ fertilization and from 47 to $92 \%$ with the severity of water stress. On average, values exceeded the quality standard for most commercial agreements (80\%), only when moderate and severe water stress occurred or high nitrogen rate was applied.

Table 5

Vitreous kernels, dry gluten and SDS test of grain at physiological maturity as affected by $\mathrm{N}$ rate and water stress

\begin{tabular}{llll}
\hline Treatment & Vitreous kernels $(\%)$ & Dry gluten $(\%)$ & SDS test (mm) \\
\hline N rate & & & \\
N0 & $65.3 \mathrm{a}$ & $8.4 \mathrm{a}$ & $33.1 \mathrm{a}$ \\
NL & $73.3 \mathrm{~b}$ & $9.4 \mathrm{ab}$ & $37.6 \mathrm{~b}$ \\
NH & $85.7 \mathrm{c}$ & $10.2 \mathrm{~b}$ & $43.3 \mathrm{c}$ \\
Water stress & & & \\
FI & $46.8 \mathrm{a}$ & $8.3 \mathrm{a}$ & $33.1 \mathrm{a}$ \\
LWS & $63.9 \mathrm{~b}$ & $9.3 \mathrm{~b}$ & $37.4 \mathrm{~b}$ \\
MWS & $85.0 \mathrm{c}$ & $9.6 \mathrm{~b}$ & $37.7 \mathrm{~b}$ \\
HWS & $91.6 \mathrm{~d}$ & $9.7 \mathrm{~b}$ & $41.6 \mathrm{c}$ \\
\hline
\end{tabular}

Within treatment $\mathrm{N}$ rate and water stress, values followed by the same letter are not significantly different at $P \leq 0.05$. 
Dry gluten and SDS test values increased with the gain of the $\mathrm{N}$ rate and with the severity of water stress (Table 5). The highest $\mathrm{N}$ rate increased dry gluten and SDS test by $1.8 \%$ and $12.2 \mathrm{~mm}$, compared to N0, and the most severe water stress increased values by $1.4 \%$ and $8.5 \mathrm{~mm}$.

\section{Discussion}

The relative contribution of current assimilation and remobilization of carbon and nitrogen during grain filling in $\mathrm{N}$ fertilized and unfertilized durum wheat plants, subjected to water deficit during grain filling, was investigated in a 2-year research. The year effect was non-significant for all characters, since temperature and rainfall during wheat growing season were similar and moreover close to the long-term averages. The two varieties, Appio and Creso showed a similar behaviour, and $\mathrm{N}$ fertilizer rate and water stress induced similar changes in dry matter yield, accumulation and remobilization of assimilates and grain quality. This was expected, owing to the close genetic background of the two varieties.

In wheat, the ability to supply assimilates to the grain and the potential kernel number per unit area are already determined at anthesis. Indeed, the number of spikes per unit area is set before culm elongation starts and the number of flowers per spike is established between the beginning of culm elongation and heading (Li et al., 2001). In our research, high-N plants had higher grain yield compared to unfertilized ones, as $\mathrm{N}$ deficiency reduced plant dry weight and plant storage capacity. The former decreased the photosynthetic capacity and the assimilates available for remobilization, the latter decreased the number of kernels per spike. Water stress during grain filling greatly reduced grain yield, and the yield reduction resulted from a little decrease of the number of kernels per spike and a great decrease of mean kernel weight. These results suggest that water stress affects both the fertilization of flowers and the rate of grain filling. Zhang et al. (1998), Dencic et al. (2000) and Guttieri et al. (2001) found that drought reduced grain yield due to a reduction in kernel growth rate, whereas Kobata et al. (1992) and Altenbach et al. (2003) demonstrated that kernel size, and thus yield reduction, was due to the shortening of the duration of grain filling. In our research, the duration of grain filling was not modified either by water deficit or by nitrogen treatments. Moreover, the effect of water deficit was primarily directed to grain, since it did not affect dry mass of vegetative organs, whose growth was concluded by anthesis. As a consequence, $\mathrm{HI}$ was greatly reduced by water deficit at all $\mathrm{N}$ rates.

Consistently to the findings of Gooding et al. (2003) and Labuschagne et al. (2006), our results have also demonstrated that both $\mathrm{N}$ fertilization and post-anthesis water stress slightly increased grain protein concentration and greatly improved grain quality, measured through the percentage of vitreous kernels, SDS test and gluten concentration. This indicates that protein quality is more sensitive to $\mathrm{N}$ availability and water stress than total protein concentration. However, acceptable grain quality was obtained in this research only at high $\mathrm{N}$ fertilization (Mahaut, 1997; D’Egidio et al., 2005).
Nitrogen concentration in grain was greatly affected by $\mathrm{N}$ rate, while it was affected by water stress only at the severest level and in high fertilized plants. It has been evidenced that both drought stress and high temperatures during grain filling tend to increase grain protein concentration in controlled environment conditions (Triboi and Triboi-Blondel, 2002; Gooding et al., 2003). For field-grown wheat, however, effects of drought were less consistent, since increased rainfall or irrigation during grain filling resulted positively associated with grain protein concentration in some experiments, but not in others (Smith and Gooding, 1996; Olesen et al., 2000; Garrido-Lestache et al., 2005). The increase of $\mathrm{N}$ concentration in grain with increasing soil drought during grain filling has been attributed to the higher sensitivity to water stress of starch deposition compared to protein deposition (Jenner et al., 1991; Daniel and Triboi, 2002; Gooding et al., 2003; Triboi et al., 2006). Our results support this conclusion only for well fertilized plants at severe water stress. All other conditions of $\mathrm{N}$ shortage and water stress similarly hampered starch and protein deposition, so that $\mathrm{N}$ concentration in grain was not modified.

Post-anthesis dry matter and $\mathrm{N}$ accumulation and remobilization in durum wheat plants were increased by $\mathrm{N}$ availability and decreased by water stress. However, the magnitude of the $\mathrm{N}$ effect was greatest at full irrigation so that, when water stress occurred, accumulation and remobilization of dry matter and $\mathrm{N}$ was greatly reduced, especially in high-N plants. Thus, nitrogen status of the plant was found to modify plant tolerance to water stress, as the high- $\mathrm{N}$ plants were more sensitive to drought than the unfertilized ones. We suggest that the latter have a lower demand for water caused by their lower transpiration surface coupled to a higher uptake ability caused by their larger root mass. Conversely, low and moderate water stress did not substantially modify the patterns of dry matter and nitrogen deposition in grain, which is not surprising, since it has been shown that mild soil drying may not seriously disrupt phloem function, and phloem translocation is less susceptible to drought than leaf photosynthesis (Boyer and McPherson, 1975; Yang and Zhang, 2006). In addition, Palta et al. (1994), Sinclair et al. (2000) and Xu et al. (2006) reported that modest soil drought enhanced $\mathrm{N}$ transfer from vegetative organs to grain, thus increasing the contribution of remobilized $\mathrm{N}$ to $\mathrm{N}$ grain content.

In conclusion, the results from this study demonstrated that in durum wheat post-anthesis water stress greatly reduced grain yield at all $\mathrm{N}$ rates. Plants grown at high $\mathrm{N}$ availability, however, obtained higher grain yields at all water stress levels.

\section{References}

Altenbach, S.B., DuPont, F.M., Kothari, K.M., Chan, R., Johnson, E.L., Lieu, D., 2003. Temperature, water and fertilizer influence the timing of key events during grain development in a US spring wheat. J. Cereal Sci. 37, 9-20.

Arduini, I., Masoni, A., Ercoli, L., Mariotti, M., 2006. Grain yield, and dry matter and nitrogen accumulation and remobilization in durum wheat as affected by variety and seeding rate. Eur. J. Agron. 25, 309-318.

Asseng, S., van Herwaarden, A.F., 2003. Analysis of the benefits to wheat yield from assimilates stored prior to grain filling in a range of environments. Plant Soil 256, 217-239. 
Asseng, S., Keating, B.A., Fillery, I.R.P., Gregory, P.J., Bowden, J.W., Turner, N.C., Palta, J.A., Abrecht, D.G., 1998. Performance of the APSIM-wheat model in Western Australia. Field Crops Res. 57, 163-179.

Asseng, S., Turner, N.C., Keating, B.A., 2001. Analysis of water- and nitrogenuse efficiency of wheat in a Mediterranean climate. Plant Soil 233, 127-143.

Austin, R.B., Morgan, C.L., Ford, M.A., Blackwell, R.D., 1980. Contribution to grain yield from pre-anthesis assimilation in tall and dwarf barley phenotypes in two contrasting seasons. Ann. Bot. 45, 309-319.

Biddinger, F.R., Musgrave, R.B., Fisher, R.A., 1977. Contribution of stored preanthesis assimilate to grain yield in wheat and barley. Nature 270, 431433

Borghi, B., Corbellini, M., Minoia, C., Palumbo, M., Di Fonzo, N., Perenzin, M., 1997. Effects of Mediterranean climate on wheat bread-making quality. Eur. J. Agron. 6, 145-154.

Boyer, J.S., McPherson, H.G., 1975. Physiology of water deficits in cereal crops. Adv. Agron. 27, 1-23.

Campbell, C.A., Zentner, R.P., Selles, F., McConkey, B.G., Dyck, F.B., 1993. Nitrogen management for spring wheat grown annually on zero-tillage: yields and nitrogen use efficiency. Agron. J. 85, 107-114.

D'Egidio, M.G., Belocchi, A., Brandini, R., Fornara, M., Desiderio, E., 2005. Monitoraggio qualitativo della produzione nazionale di frumento duro. In: Proceedings of the Symposium Ricerca ed innovazione per le produzioni vegetali e la gestione delle risorse agro-ambientali, vol. 20-22, Foggia, Italy, pp. 23-24.

Daniel, C., Triboi, E., 2002. Changes in wheat protein aggregation during grain development: effects of temperatures and water stress. Eur. J. Agron. 16, $1-12$.

Dencic, S., Kastori, R., Kobiljski, B., Duggan, B., 2000. Evaluation of grain yield and its components in wheat cultivars and landraces under near optimal and drought conditions. Euphytica 113, 43-52.

Dick, J.W., Quick, J.S., 1983. A modified screening test for rapid estimation of a gluten strength in early generation durum wheat breeding lines. Cereal Chem. 60, 315-318.

Edhaie, B., Alloush, G.A., Madore, M.A., Waines, J.G., 2006. Genotypic variation for stem reserves and mobilization in wheat: II. Postanthesis changes in internode water-soluble carbohydrathes. Crop Sci. 46, 2093 2103.

Ehdaie, B., Waines, J.G., 2001. Sowing date and nitrogen rate effects on dry matter and nitrogen partitioning in bread and durum wheat. Field Crops Res. 73, 47-61.

Gallagher, J.N., Biscoe, P.V., Hunter, B., 1976. Effects of drought on grain growth. Nature 264, 541-542.

Gan, S., Amasino, R.M., 1997. Making sense of senescence. Plant Physiol. 113, 313-319.

Garrido-Lestache, E., López-Bellido, R.J., López-Bellido, L., 2005. Durum wheat quality under Mediterranean conditions as affected by $\mathrm{N}$ rate, timing and splitting. $\mathrm{N}$ form and S fertilization. Eur. J. Agron. 23, 265-278.

Gooding, M.J., Ellist, R.H., Shewry, P.R., Schofield, J.D., 2003. Effects of restricted water availability and increased temperature on the grain filling, drying and quality of winter wheat. J. Cereal Sci. 37, 295-309.

Guttieri, M.J., Stark, J.C., O’Brien, K., Souza, E., 2001. Relative sensitivity of spring wheat grain yield and quality parameters to moisture deficit. Crop Sci. 41, 327-335.

Jenner, C.F., Ugalde, T.D., Aspinall, D., 1991. The physiology of starch and protein deposition in the endosperm of wheat. Aust. J. Plant Physiol. 18, 211-226.

Kobata, T., Palta, J.A., Turner, N.C., 1992. Rate of development of postanthesis water deficits and grain filling of spring wheat. Crop Sci. 32, 1238 1242 .

Labuschagne, M.T., Meintjes, G., Groenewald, F.P.C., 2006. The influence of different nitrogen treatments on the size distribution of protein fractions in hard and soft wheat. J. Cereal Sci. 43, 315-321.

Li, C., Cao, W., Dai, T., 2001. Dynamic characteristics of floret primordium development in wheat. Field Crops Res. 71, 71-76.

López-Bellido, L., López-Bellido, R.-J., Castillo, J.E., López-Bellido, F.J., 2001. Effects of long-term tillage, crop rotation and nitrogen fertilization on bread making quality of hard red spring wheat. Field Crops Res. 72, 197-210.
Mahaut, B., 1997. Comment Evalue-t-on la Qualité d'un blé dur? Blé dur. Objective Qualité. ITFC, ONIC, Paris, p. 49.

Masoni, A., Ercoli, L., Mariotti, M., Arduini, I., 2007. Post-anthesis accumulation and remobilization of dry matter, nitrogen and phosphorus in durum wheat as affected by soil type. Eur. J. Agron. 26, 179-186.

Moonen, C., Masoni, A., Ercoli, L., Mariotti, M., Bonari, E., 2001. Longterm changes in rainfall and temperature in Pisa, Italy. Agr. Med. 130, $11-22$.

Moragues, M., Garcia del Moral, L.F., Moralejo, M., Royo, C., 2006. Yield formation strategies of durum wheat landraces with distinct pattern of dispersal within the Mediterranean basin II. Biomass production and allocation. Field Crops Res. 95, 182-193.

Olesen, J.E., Mortensen, J.V., Jorgensen, L.N., Andersen, M.N., 2000. Irrigation strategy, nitrogen application and fungicide control in winter wheat on a sandy soil. I. Yield, yield components and nitrogen uptake. J. Agric. Sci. Cambridge 134, 1-11.

Ozturk, A., Aydin, F., 2004. Effect of water stress at various growth stages on some quality characteristics of winter wheat. J. Agron. Crop Sci. 190, 93-99.

Palta, J.A., Kobalta, T., Turner, N.C., Filllery, I.L., 1994. Remobilization of carbon and nitrogen in wheat as influenced by post-anthesis water deficit. Crop Sci. 34, 118-124.

Pampana, S., Mariotti, M., Ercoli, L., Masoni, A., 2007. Accumulation and remobilization of dry matter, nitrogen and phosphorus in durum wheat as affected by genotype and environment. Ital. J. Agron. 2, 3-13.

Pan, J., Zhu, Y., Cao, W.X., 2007. Modeling plant carbon flow and grain starch accumulation in wheat. Field Crops Res. 101, 276-284.

Papakosta, D.K., Gagianas, A.A., 1991. Nitrogen and dry matter accumulation, remobilization, and losses for Mediterranean wheat during grain filling. Agron. J. 83, 864-870.

Plaut, Z., Butow, B.J., Blumenthal, C.S., Wrigley, C.W., 2004. Transport of dry matter into developing wheat kernels and its contribution to grain yield under post-anthesis water deficit and elevated temperature. Field Crops Res. 86, $185-198$

Sinclair, T.R., Pinter, P.J., Kimball, B.A., Adamsen, F.J., LaMorte, R.L., Wall, G.W., Hunsaker, D.J., Adam, N., Brook, T.J., Garcia, R.L., Thompson, T., Leavitt, S., Mattias, A., 2000. Leaf nitrogen concentration of wheat subjected to elevated $\left[\mathrm{CO}_{2}\right]$ and either water or $\mathrm{N}$ deficits. Agric. Ecosyst. Environ. $79,53-60$

Smith, G.P., Gooding, M.J., 1996. Relationships of wheat quality with climate and nitrogen application in regions of England (1974-1993). Ann. Appl. Biol. 129, 97-108.

Spiertz, J.H.J., De Vos, N.M., 1983. Agronomical and physiological aspects of the role of nitrogen in yield formation of cereals. Plant Soil 75, 379391.

Steel, R.G.D., Torrie, J.H., Dickey, D.A., 1997. Principles and Procedures of Statistics: A Biometrical Approach. McGraw-Hill, New York.

Tarantino, E., Onofrii, M., 1991. Determinazione dei coefficienti colturali mediante lisimetri. In: Proceedings of the Symposium Irrigazione e ricerca, 1988, Bologna, Italy, pp. 119-136.

Triboi, E., Triboi-Blondel, A.-M., 2002. Productivity and grain or seed composition: a new approach to an old problem. Eur. J. Agron. 16, 163186.

Triboi, E., Martre, P., Girousse, C., Ravel, C., Triboi-Blondel, A.-M., 2006. Unravelling environmental and genetic relationships between grain yield and nitrogen concentration for wheat. Eur. J. Agron. 25, 108-118.

van Herwaarden, A.F., Farquhar, G.D., Angus, J.F., Richards, R.A., Howe, G.N., 1998a. 'Haying-off', the negative grain yield response of dryland wheat to nitrogen fertiliser. I. Biomass, grain yield, and water use. Aust. J. Agric. Res. 49, 1067-1081.

van Herwaarden, A.F., Angus, J.F., Richards, R.A., Farquhar, G.D., 1998b. 'Haying-off', the negative grain yield response of dryland wheat to nitrogen fertiliser. II. Carbohydrate and protein dynamics. Aust. J. Agric. Res. 49, 1083-1093.

Xu, Z.Z., Yu, Z.W., Wang, D., 2006. Nitrogen translocation in wheat plants under soil water deficit. Plant Soil 280, 291-303.

Yang, J., Zhang, J., 2006. Grain filling of cereals under soil drying. New Phytol. $169,223-236$ 
Yang, J., Zhang, J., Zhu, Q., Wang, L., 2000. Remobilization of carbon reserves is improved by controlled soil-drying during grain filling of wheat. Crop Sci. $40,1645-1655$.

Yang, J., Zhang, J., Wang, Z., Zhu, Q., Liu, L., 2001. Water deficit-induced senescence and its relationship to the remobilization of pre-stored carbon in wheat during grain filling. Agron. J. 93, 196-206.
Zadoks, J.C., Chang, T.T., Konzak, C.F., 1974. A decimal code for the growth stages of cereals. Weed Res. 14, 415-421.

Zhang, J., Sui, X., Li, B., Su, B., Li, J., Zhou, D., 1998. An improved water-use efficiency for winter wheat grown under reduced irrigation. Field Crops Res. 59, 91-98. 